\title{
RELIGION AND STATE RELATION IN PERSPECTIVE OF INDONESIAN ISLAMIC ORGANIZATION IN REFORMATION ERA*
}

\author{
Muntoha \\ FH UII and UII PSI, email: muntoha.syaikh @ yahoo.com
}

\begin{abstract}
Penelitian ini membabas dinamika relasi agama dan negara di Indonesia di era reformasi menurui pandangan NU, Mubammadiyah, HTI, MMI, dan Salafi. Persoalan penting yang digali penelitian ini adalah bagaimana onganisasi massa Islam mengekspresikan baik ketidakpuasan maupun kepuasan terkait dengan relasi agama-negara dalam negara Pancasila di Indonesia di era reformasi. Penelitian ini dibarapkan memberikan kontribusi untuk penjembangan Iskam dalam konteks keindonesiaan untuk memperkuat gagasan dan filosofi Pancasila; dan dapat menjadi dasar pertimbangan dari organisasi-organisasi Islam, organisasi sosial-politik, dan bangsa untuk memikirkan kembali relasi tersebut dari sudut arti pentingnya Pancasila untuk masa depan bangsa. Temuan penelitian ini, menggambarkan pandangan yang dipreseniasikan oleb oryanisasi Ishm variatif dari tidak tunggal dalam melibat bubungan agama dan negara di Indonesia di era reformasi. Ormas-ormas Islam berbeda strategi dalam mengartikulasikan wacana tentang relasi agamu dan negara. Semua ormas Islam tersebut merasa kurang puas terbadap konstruksi bubungan agama dan negara di era reformasi.
\end{abstract}

مستخدص

تناقش هذه الدراسة ديناميات العلافة بين الدين والدولة في اندونيسيا في عهد الإصلاح في رأي NU ـ المحمدية؛

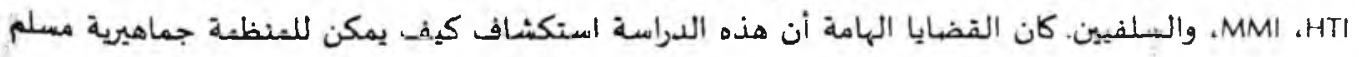

- This article is a summary of the results of interdisciplinary research on Indonesian Islamic Organization Perspective Regarding Religion and State Relation in Pancasila state in Indonesia in Reformation Era. This reseatch was funded by Research and Social Service Directorate (DPPM) of Islamic University of Indonesia (UID) Yogyakarta.

- Interdisciplinary research was conducted by a research team consisting of Muntoha (coordinator), Edi Safitri and Nur Khalik Ridwan (members). 
سواء كانت صريحة أو عدم الرضا الورتياح المرتبطة العلاقات الدين بالدولة في الدولة البانشاسيلا في إندونيسيسا

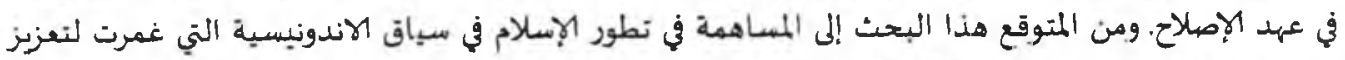

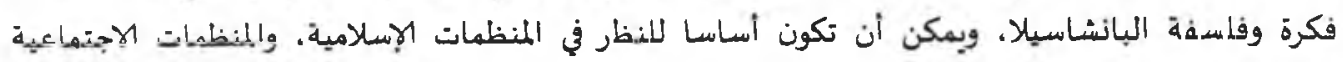

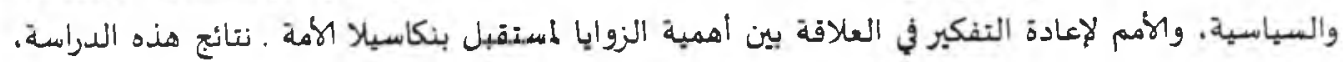

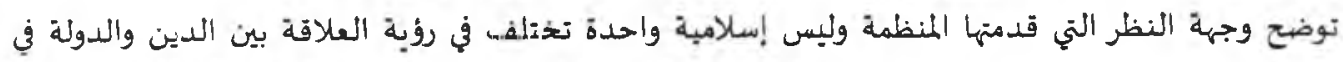

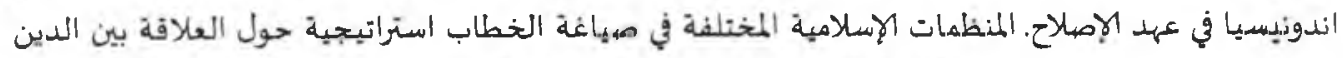
والدولة. جميع المنظهات الإسلامية بشعرون بقدر أقل راض عن العلاقة بين الدين وبناء الدولة في عهد الإصلاح

Keywords: religion and state relations, Reformation era, Indonesian Islamic organization, and country, reformation era, Islamic organizations, and Pancasila.

\section{A. Introduction}

In the notion of reformation, Indonesia has gone a long way in the transition to democracy, dismantle and build the basic structure of political, social, legal, economic, defense, including the relationship between religion and the State. Within that frarnework, first, the reformation creates, ratified, and develop laws adapted to the climate of reformation, secondly, the arrangement and creation of state iristitutions is driven by the philosophy of political and economic liberalization.

The impact of these reformations is a space created to build the nation freedom to move forward. In addition, another implication also spawned foreign investment philosophy that threatens the independence of the nation, which is still a lot of poverty, autonomy without leadership, a huge debt, rampant corruption, the tise of violence in the name of religion, the birth of the Sharia-based local laws.

Political liberalization and encouragement to assert social groups in this nation fundamentally, even blindly, until there are certain groups, which then characterizes life in an age of reformation, namely to create violence. At the same time, these groups do not discuss Pancasila the basis of the nation, the need to consider the aspect of unity within Pancasila, appreciate it as part of 
citizens' rights. This causes fading national solidarity, coupled with the people's party away and injustice felt by the people in these areas, making it a candidate of reformation can not be viewed simply.

In the midst of such a situation, the relationship between religion and the state has become a part of the reformation movement. Among the forms is the belief in the recognition of the group penghayat Adminduk Act of 2006, Human Rights Law, and others, but if all such laws satisfy the justice and the desire to develop a view of the corner of Pancasila, still raises a lot of questions and need serious study.

In addition, it also seems increasingly absence of Pancasila in public debates during the 10 years of reformation in framing the relationship between religion and the state, because one side: a tendency to argue on the subject of human rights groups alone, and another group carrying of religion alone. This fact encouraged the practice of Pancasila experience ever closed his discourse by the Soeharto regime and political freedom in the reformation era. Finally, values and vision of Pancasila farther away from the practice leader of this country, and the absence of a sense of unity as a nation.

Pancasila proved to be a unifying its value in a matter of unifying the nation, despite facing many challenges from outside and from within. Pancasila should also guide the direction of the positive law legislation and orient national development in various respects; Pancasila should also be signs in the public domain and inter-group relations, rather than theological sovereignty of each religion, beliefs, and group. Therefore, KH. Abdurrahman Wahid once wrote that the Pancasila as the national ideology "Pancasila is sublime agreement between all groups living in Indonesia. However, an agreement, whatever seluhur not be much work if not seated in a clear status. Therefore, the Indonesian nation is noble agreement finally formulated as a philosophy and ideology of the nation state. Ideology of the nation, meaning that every citizen of the Republic of Indonesia is bound by its provisions are very basic, which is contained in the five precepts.

Outlook on life and attitude of the citizens as a whole should be based on the Pancasila as a whole, not just individual precepts. As the state 
philosophy, Pancasila status as a framework of thinking that must be followed in drafting legislation and legal products that others, in the formulation of government policy and set the formal relationship between the institutions and individuals who live in areas of the country. The way of think the whole nation in its scope determined by a philosophy that must be continuously maintained the existence and consistency by the state, so that continuity of thought growing state will also be well maintained ".

Even so, not denied, in social discourse, Pancasila as an ideology, sometimes quipped as "nonsensical state": not a religious state and not a secular state. This assumption may not be entirely correct when not reviewing in more detail the forms in question, because it simply uses the phrase to refer to the Pancasila state would be simplistic and cut open debate Pancasila as an ideology. In fact Pancasila state is a state that provides a space for religious groups to fight for their rights, but do not turn off other groups, so too secular groups are given space to live, with no deadly religious groups. This fact explains the non-acceptance of the dominant currents, either by groups or by groups of secular religion, with remains grounded in democracy.

This fact is confirmed the existence of examples of post-reformation aspirations of the Jakarta Charter, it did not get a scoop hails from many circles when the proposed return. This encourages constant meaning over form the relationship between religion and state in the Pancasila state, although there are laws that guarantee human rights, law Adminduk, and others contained in the various laws and regulations. Various religious violence committed in the name of a particular group with a particular pretext anyway, are not rewarded properly or tend to be left, also signifies the relationship of religion and state form in Indonesia is not finished and is still looking for its shape.

Thus, the progress of reformation in the field of the relationship between religion and the state department of Pancasila, need to re-viewed and analyzed, since liberalization reformations that became an icon of development, have the potential to support a positive way, but also there were contradictory and against the view of Pancasila. In order to shape the relationship between religion and the state are not yet completed it can be directed to the progress of 
the nation, rather than destroy, of course need to see and examine the point of view of the group Islamic organizations, as a potential group and while protecting against Pancasila. Reformation meant that the relationship between religion and the state has yet to finish and continue to look for the formulation, including among Islamic organizations.

Based on the above rationale, the main issue of this study is how the construction philosophy of religion and state relations in the era of reformation in the state of RI; What forms of religion and state relations from the perspective of Pancasila and responded by Islamic organizations? Is the form of policies and building the relationship between religion and the state in the era of reformation has met their aspirations, and how they put the existing dissatisfaction or satisfaction according to the Indonesian Islamic organization construction?

This study uses the theory of unified paradigm and symbiotic paradigm as tool of analysis. In this integrative paradigm, as mentioned Spinoza, Adam Muller and Hegel that the life of the nation and the role of the state is not just a function of a person or group guarantees but also to ensure the interests of society as a holistic entity. The state is the organic unity of suciety and arranged integrally. In it all the groups, all the parts, all the individuals are closely related to each other. This thinking is based on the principle of unity between the people and the leadership and unity within the country entirely.

Whereas symbiotic paradigm, religion and state are considered related in a symbiotic relationship that is reciprocal and mutual need. In this case because the state requires religious state, religion to thrive. Instead the country also requires religion, because religion, countries can thrive in ethics and moral guidance. On that basis, the state has a clear religious and reciprocity. The thinking among scholars embraced Islam like Ibn Taymiyyah; Muhammad Abduh, Al-Afghani Jamaludir, Yusuf Al-Qaradawi, Al-Mawardi and others.

Ibn Taymiyyah stated that the powers that govern human life is the greatest religious obligation. Without the power of the state, then religion can not be upright. This opinion meligitimasikan religion and state are two different intensities, but need each other. By karenannya, the current constitution in this 
paradigm not only from the social contract, but it could have been tinged with religious law. In this concept, the sharia (Islamic law) occupies a central position; sources of legitimacy of the political reality. In a symbiotic paradigm very clear that there will "privileging" the majority of religious believers (Muslims) impose religious laws under the legitimacy of the state. Or at least not because of this symbiotic nature, religion law has a chance coloring state laws, in particular problems bahklan not be used as a rule of law state.

In the context of this study, both the above Theory, and symbiotic integrative theory-will be used to explain how the state-religion relations in the Pancasila state. Integrative theory philosophy construction is expected to explain their relationship in the state of RI. As a basic philosophy of life and a nation of Indonesia, Pancasila serve as a guide in carrying out activities and life in all areas.

\section{B. Results and Discussion}

1. Philosophy construction of religion and state relation in the reformation era

Philosophical hilosophical construction relationship between religion and the state after the reformation, each addressing different groups and construct, which can be described below.

First, NU saw the philosophy of religion and state relations in the era of reformation is always related to a matter of how Islam sees the form of the state. According to NU, Islam is the perfect religion and belief comprehensive in its followers, including the country's problems. There are even rules that are often cited by the NU, where the state is seen as a part of something that obligation is not complete except with something that then something is obligatory.

Referring to Al-Ghazali, NU saw power and religion are twin sisters. Keligion is the foundation and power are his bodyguards. But NU distinguish shapes his country, which he said it was left to men to define their own choice, in accordance with the demands of the times, places and benefit, because it's part of the business world. Caliphate system, monarchy, or a republic is simply 
an alternative that has become a fact of history. From this angle, NU received nation-state form the basis of Pancasila, while still trying to provide opportunities and adopt the values embraced by the Muslims, especially the ideology espoused Aswaja NU. Pancasila by NU give it space in the democratic arena. According to NU philosophy of religion and state relations in the era of reformation, according to NU should not be separated and can not be separated from the construction philosophy of Pancasila which emphasizes on the aspects of what religion can play a role, but it should still gracefully against other aspiration.

Second, Muhammadiyah see the relationship between religion and the state after the reformation of the corner of his views on Pancasila, because according Muhammadiyah religion-state relations should be based on the philosophical constitution, in which Muslims still play a role. In a trial based Tanwir Muhammadiyah in Yogyakarta, akslamasi stated that Muhammadiyah to support Indonesia as a state ideology. However, there also remain among the Muhammadiyah politics no longer willing ijtihad Pancasila state, but the numbers are examined according to sources, had never been in the survey. Most importantly, the current organization agrees Pancasila. Philosophy of religion-state relations in the post-reformation views Muhammadiyah, likened Pancasila is the ticket, so to get in have to buy first. Pancasila is still considered philosophically make room for religion, but not as the state. This space can be played in many ways, so it must be played to borrow a phrase Ma'Arif Shafi'i Muslims, especially salt Muhammadiyah politics should not play politics lipstick. If the lipstick looks on the lips, but it was not there, but if the salt, do not look at the water, but the water is salty.

Third, HTI see the relationship between religion and the state after the reformation of the legal comer of the country is an Islamic state, in which the Islamic system of government that is required by the Lord of the universe is the caliphate system. Therefore, HTI is an arm of HT the same world view, in principle incompatible with the nation-state based on Pancasila. Countries with the philosophy and principles of Pancasila, it is not an Islamic state, and because it is not an Islamic state, he includes categorized as Darul Kuffar. 
Relationships state religion after the reformation is not important anymore, because of the essentially according to the HTI was wrong. They then replaced st with a critical reformation, democracy, capitalism, corruption, exploitation of nature, poverty, and others, in the hope the system will be replaced with a caliphate.

Fourth, according to MMI the relation between religion and state in reformation rea states, based on the concept of propaganda, which invites people to the Oneness of Allah, and His Shari'ah apply, as the only way of life (manhajul bayab), statutes and regulations and the rules of human life. Human prohibited juxtaposing another order next Shari'ah of Allah as the order of life in the care of any business. While jihad is meant here is, earnest efforts to promote and implement Islamic Sharia in all aspects of life, both personal, family, community, state and nation; including resistance (defense business) when attacked.

Based on the explanation above, MMI actually asking the question "is it true that Pancasila the basis of the Republic of Indonesia?" Given that it is also a virtue Belief in God Almighty, and the question of what the definition of Pancasila state? After all, until now we have never heard of definition. MMI does not expressly accept Pancasila and Pancasila also flatly refused. According to $\mathrm{MMI}$, according to his spokesman, if we agree on God it is a religious concept, it should state that based on Pancasila Belief in God Almighty. According to Prof. A. Zairin, $\mathrm{SH}$ a Pancasila commentators say "in the Pancasila state based on God is the state that makes laws must not conflict with religious teachings". A. The issue opinion This Zairin not be the opinion Indonesian government. So according to the MMI, if you agree that the Belief in God Almighty as the basis, then the relationship of religion in the era of reformation in his opinion, all statutory provisions must not. conflict with religious teachings.

Fifth, Salafis see the relationship between religion and the state of the two angles: any rules and systems that prevail among Muslims must be based on the Qur'an and hadith: but he was also based on the attitude that the legitimate government recognized by Muslims should not diberontak. Pancasila 
in principle is not the Qur'an and hadith, thus making construction in building the Islamic society, beyond that is irrelevant. But not explicitly linked Pancasila with this matter. There is an impression Salafis avoided talking about Pancasila. On the basis of it, the Salafis mostly developing cultural aspects by establishing schools, building studies of society in accordance with the al-Quran and Hadith, which is done is purified and movement in society, not politics. For those taking care of Pancasila will enter the realm of politics.

\section{Forms of religion and state relations from Pancasila standpoint}

The second part of the study is to see how the religion-state relation in the reformation era from the standpoint of Pancasila itself, and how they respond. Seen from this aspect, can be explained below.

First, NU saw the construction philosophy of relationships which have been described in both the amendment and the law, democracy and the legal basis must be adhered to, but should remain publicly controlled open opportunities, and can be corrected. The public control for NU is part of the implementation of democracy's most important, because if later on found things that need to be changed, then the public control was modified by public demands through democratic institutions.

Second, Muhammadiyah, also looked at the relationship between teligion and state that has been described in the Amendment and the Act, such as the blasphemy law, was valid. Muhammadiyah see there needs to be rules and instruments are more firmly that religion plays a role, so that the deviant sects should be banned and not allowed.

Third, HTI is inconsistent, because in some ways he considers "spirit" Islamic law is contained in Pancasila, but the system used every different regimes. Shape in the reformation period considered under neoliberalism and not clarified to be criticized. Pancasila must be supported by a more solid juridical devices. According to him, should be regulated and what should not be done. This is where the Pancasila is not seated. HTI in fact there should be a state doctrine caliphate. Which is contrary to the point of view of Pancasila. 
Fourth, MMI view, the relationship between religion and state construction in the post-reformation Pancasila state, is still not in line with Islamic law, because Islam is supposed to be the basis of a state, and criticized Pancasila is not clear, since it is supposed that the deity is maha Esa mean religion should be set countries. When applying for a draft amendment to the Constitution 45 version of MMI and many agreed it was not in accordance with the MMI. For the MMI remains a slogan of jihad to implement Islamic law must still be done.

Fifth, salafi avoid talking about the assessment of the relationship between religion and state construction after the reformation, although in principle they agree the state should be based on the Qur'an and hadith. Because of the purification is carried over in many ways, it does not make the source of the Qur'an and hadith as, is a mistake.

\section{Attitudes and Aspiration of Indonesian Islamic organization regarding Religion and State relationship in reformation era.}

First, NU saw reformations produce things that are useful, but we should not turn a blind eye to the realities of concern, which is not bad as a result we want from reformation. 1945 amendments were made in haste and lack of precision has spawned legislation rules that harm the people, nation, and state. NU invited to this nation back to Indonesia khitthah 1945, in the sense of returning to the spirit of the Proclamation, return to the values of Pancasila and the 1945 Constitution mandated.

In the overall assessment of the reformations, the issue of the relationship between religion and the State, are not discussed specifically, because NU believes that Pancasila has provided space for the formulation of the Act the role of religion and character building of the nation, but NU assess the dynamics of the proposed reformations as a matter of the Jakarta Charter, regulations Shari'a, Ahmadiyah case, and judicial PNPS No. 1 of 1965 on religious defamation.

NU does not agree that the Jakarta Charter revived. About Sharia law, NU did not agree, because it can interfere with the integrity of the Indonesian people. Areas can make their own laws, and it can not be allowed. The 
important thing is not to impose Islamic law textually, but took his enthusiasm for the common good. NU on Ahmadiyah condemned the acts of violence against the Ahmadiyah community in Indonesia, but deviate from recognized Ahmadiyah as Islam, and at the same time NU will not tolerate judgment in a violent manner. PWNU of East Java harder, support freezing of the Ahmadiyah Muslim Community. As for the judicial review of Law. 1 of 1965 on religious defamation, $\mathrm{NU}$ rejected the judicial review, thus agree with the article blasphemy.

Second, HTI look very dissatisfied on reformation, including the relationship between religion and the state, which should be fought because the Caliphate, not democracy but in some cases also responded HTl despite the Pancasila state frame: Problem Shari'ah regulations HII agree because procedurally, by laws was born through a legitimate political process. 'That is, through discussion and procedures as other local regulations. Law judicial matter. 1 of 1965 on religious defamation, HTI those who refuse the test material, and said that the Court should have rejected the plaintiffs. Regarding the Jakarta Charter, Ismail agreed and criticized Hamzah $\mathrm{Haz}$ is considered in its favor. On Ahmadiyah, HTI agree that Ahmadiyah is heretical and the state must act to conserve the purity of religion.

Third, Muhammadiyah is also not satisfied with the results of reformation though, there are many things that can be accepted. In cases such as the Ahmadiyya, Ahmadiyya agree Muhammadiyah is misguided and should be frozen. Problem Muhammadiyah Jakarta Charter abstained, but many agree the Jakarta Charter characters alive again; while about Shari'ah regulations Muhammadiyah caution though somewhat inclined to agree, and on judicial PNPS Act 1965 Muhammadiyah disagree. Proposal must still play a role in religion in the Pancasila state.

Fourth, MMI assessing reformations is not much to realize the ideals of the Muslims implementing Islamic syari'at, because that is precisely liberalism. MMI still voiced that Islam and Islamic law is applied, avoiding the impression temains whether Pancasila should be replaced, did not give the light of the assessment. However, they voiced that it is the Islamic Shari'a should be 
implemented. In this case, MMI agrees to revive Jakarta Charter, Ahmadiyah banned because of heresy; reject judicial PNPS Act of 1965 concerning blasphemy, and strongly agree if shari'a by laws made even more.

Fifth, many Salafis do not judge the politics of reformation, but hope lives in the future must be better and should be based on the Qur'an and hadis. This proposed to go back to the Qur'an and hadis, something is never expressed by other organizations. But the Salafis are not moving at the political level, because its concern just do purification, even assembled in the organization is not in line with Islam.

\section{Closing Remarks}

In general, Indonesian Islamic organization in reformation momentum to take the work to be concerned, but their attitudes towards democracy and reformation different fundamentally, because from the beginning there who refuse to democracy and Pancasila itself. Other groups differ in terms of the explanations in the Pancasila state. Difference is also reflected in the construction of the relationship between religion and state from Pancasila viewpoint, which from the beginning there who see it as wrong from the beginning, because it is not derived from the Qur'an and hadith are ordered to form a caliphate as HTI, and some accept and develop patterns of symbiosis, a case was NU and Muhammadiyah. But in the organizations and groups that have turned out differently, for example, there recoqnize and agree the right to life Ahmadiyah, though not agree to açidah of Ahmadiyah; anyone actually be part of the plaintiffs involved in the group PNPS Act 1965; anyone disagree with local regulations Shari'a and others. This situation illustrates the relationship of Islamic groups with highly dynamic in Pancasila state, ranging from the diametric to the elementary, became part of boosters.

These groups are influenced by the attitudes and ideology from the beginning, different, and therefore, no attitude change as easy as it, as it relates to building organization. The risk is: those who still refused and were across Pancasila will remain in the periphery. Plus they are inconsistent when they are involved in such efforts Shari'ah regulations, banning Ahmadiyah, Jakarta 
Charter agrees, and agrees Act PNPS not tested, which means that there is in the Pancasila state. This inconsistency will backfire, because these groups are not steadfast in its mission.

Those who are in the Pancasila, less loud and less vigorous fight for the role of religion in the Pancasila state, because they themselves are paralyzed, due to not having a political vehicle. Muhammadiyah and NU just a moral force. While the political parties that have controlled their political parties including the changing laws and policies. So, the idea of the relationship between religion and state in the Pancasila state in the reformation cra, conflicting with each other and show the fracturing of the Islamic group.

\section{REFRENCES}

Ali, As'ad Said.2009. Negara Pancasila: Jalan Kemaslahatan Berbangsa, Jakarta: LP3ES.

Armawi Armaidy.2009. Pemikiran Filosofis Hubungan Negara dan Agama di Indonesia, dalam www.lib.ugm.ac.id. Dikases pada tanggal 17 Juni 2012.

Bamualim, Chaidir S, dan Sukron Kamil.2007. Syariab Islam dan HAM: Dampak Perda Syari'ab terbadap Kebebasan Sipil, Hak-bak Perempuan, dan non-Muslim, Jakarta: CRSC-KAS.

Carney, T.F..1972. Content Analysis A Technique for Systematic Inference from Communication. London: B.T. Batsford Ltd.

Fauzi, Ihsan Ali, dkk..2009. Laporan Pola-pola Konflik Kegamaan di Indonesia 1990. 2008, Jakarta, Yayasan Wakaf Paramadina.

Geger, Riyanto.2012. Indonesia dan Tiga Tdory negara dalam htt://www.suarakarya-online.com. di akses pada tanggal 10 Juni 2012.

Hidayatullah. Syarif, 2012. Menakar Azas pancasila pasca reformasi dalam www. kongrespancasila.com. diakses pada tanggal 13 Juni 2012 Kaelan.2003. Pendidikan Pancasila, Yogyakarta: Paradigma. 
Kaelan, 2005.Metode Penelitian Kualitatif Bidang Filsafat Paradigma bagi Penelitian Interdisipliner Bidang Filsafat, Budaya, Sosial, Semiotika, Sastra, Hukum dan Seni. Yogyakarta: Penerbit Paradigma.

Karim M Abdul.2005., Hubungan Agama-Negara Pasca Reformasi, dalam AlMawarid Edisi XIII .

Latif, Yudi.2011. Negara Paripurna: Historisitas, Rasionalitas, dan Aktualitas Pancasila, Jakarta: Gramedia Pustaka Utama.

Moelong, John Lexy.1988. Metodologi Penelitian kualitatif, Jakarta: Departemen Pendidikan dan Kebudayaan.

Oto, Atsushi, Masaaki Okamoto, dan Suaedy Ahmad (ed.)..2010, Islam In Contention: Retbinking Islam and State in Indonesia, Jakarta-Jepang-Taiwan: The Wahid Institute-CSEAS-CAPAS, Desember.

Palah. Abdul, Relasi Agama dan negara Perspektif Nabdlatul Ulama, (2011) dalam www. blog.spot.com) Dikases pada tanggal 10 Juli 2012.

Ramage, Dougias E..2002. Percaturan Politik di Indonesia, Yogyakarta: Mata Bangsa.

Simanjutak Marsilam.1994. Pandangan Negara Integralistik; Sumber, Unsur dan Riwayatnya dalam persiapannya UUD 1945. Jakarta: Pustaka Utama Grafiti.

Soekarno.2002."Ketuhanan Yang Maha Esa", dalam Pamoe Rahardjo dan Islah Gusmian (peny.).2002. Bung Kamo dan Pancasila Menuju Revolusi Nasional, Yogyakarta: Galang Press.

Tim Penulis.2011. Agama dan Kontestasi Ruang Publik: Islamisme, Konflik, dan Demokrasi, Jakarta: The Wahid Institute.

Wahid, Marzuki.2011., Agama dan Kontestasi Ruang Publik,: Islamisme, Konflik dan Demokrasi, Jakarta: the WAHID Institute

Wahid, Marzuki\& Rumadi.2001., Figib Madghab Negara. Kritik Atas Politik Hukum Islam di Indonesia, Yogyakarta: LKiS, 2001

Wakid, KH Abdurahman.1991. "Pancasila Sebagai Ideologi dalam Kaitannya dengan Kehidupan Beragama dan Berkepercayaan terhadap Tuhan Yang Maha Esa", dalam Oetoyo Usman dan Alfian (peny.), Pancasila sebagai Ideologi, Jakarta: BP7. 